\title{
Correction to: Self-organization in aqueous solutions of thermosensitive star-shaped and linear gradient copolymers of 2-ethyl-2-oxazoline and 2-isopropyl-2-oxazoline
}

\author{
Tatyana Kirila $^{1} \cdot$ Anna Smirnova ${ }^{1} \cdot$ Mikhail Kurlykin $^{1} \cdot$ Andrey Tenkovtsev $^{1} \cdot$ Alexander Filippov $^{1}$
}

Published online: 15 April 2020

(C) Springer-Verlag GmbH Germany, part of Springer Nature 2020

\section{Correction to: Colloid and Polymer Science} https://doi.org/10.1007/s00396-020-04638-Z

The author noticed that the published paper contained error. Unfortunately, the author name "Tatyana Kirila" of the article was repeated twice. Given in this paper is the correct list of authors.

The original article has been corrected.

Publisher's note Springer Nature remains neutral with regard to jurisdictional claims in published maps and institutional affiliations.

The online version of the original article can be found at https://doi.org/ 10.1007/s00396-020-04638-z

Tatyana Kirila

tatyana_pyx@mail.ru

Institute of Macromolecular Compounds of Russian Academy of

Sciences, Bolshoy pr., 31, Saint Petersburg, Russia 199004 